\section{Calcium Fertilizers Fail to Affect Pod Calcium Concentration and Yield of Four Snap Bean Cultivars}

\author{
J.M. Quintana ${ }^{1}$, H.C. Harrison ${ }^{2}$, J.P. Palta ${ }^{2}$, J. Nienhuis ${ }^{3}$, and \\ K. Kmiecik ${ }^{4}$ \\ Department of Horticulture, University of Wisconsin-Madison, Madison, \\ WI 53706-1590
}

Additional index words. calcium sulfate, calcium nitrate, green beans, Phaseolus vulgaris

\begin{abstract}
To measure the effect of added Ca fertilizer on the Ca concentration of snap bean pods, four snap bean cultivars were grown during Summer 1996 and 1997 at Hancock, Wis. Fertilizer treatments consisted of $80 \mathrm{~kg}$ of Ca per hectare applied as Ca sulfate $\left(\mathrm{CaSO}_{4} \cdot 2 \mathrm{H}_{2} \mathrm{O}\right)$ or Ca nitrate $\left[\mathrm{Ca}\left(\mathrm{NO}_{3}\right)_{2}\right]$, and the control (no Ca applied. The experimental design was a randomized complete block with a factorial set of treatments $(4 \times 3)$. Calcium sulfate was applied at planting, whereas Ca nitrate was split applied four times at weekly intervals starting 1 week before flowering. Yield and Ca concentration in pods were determined. The statistical analysis showed no significant effect of Ca fertilizers on pod Ca concentration or yield. A strong cultivar effect was detected for both parameters measured. 'Evergreen' (5.47 mg Ca per gram dry weight) had the highest pod Ca concentration and 'Labrador' (4.10 mg Ca per gram dry weight) the lowest. No significant fertilizer $\times$ cultivar interactions were observed. Results for pod Ca concentration remained consistent, even when significant year effects were found for both parameters.
\end{abstract}

Calcium nutrition has a significant impact on human growth and health. Milk and dairy products are the main sources of $\mathrm{Ca}$ in the United States, with green, leafy vegetables also providing good sources of Ca (Macrae et al., 1993). Snap beans contain low levels of oxalic acid, which binds Ca. Calcium from beans is absorbed by the human body as well as or better than Ca from milk (Grusak et al., 1996). A 100-g (1 cup) serving of fresh snap beans can provide $56 \mathrm{mg}$ of $\mathrm{Ca}$, which accounts for $\approx 5 \%$ of the minimum daily requirement. Because of their nutritional value and popularity among teenagers (Pao et al., 1982), snap beans are a potentially important source of dietary $\mathrm{Ca}$. Therefore, any increase in bean

Received for publication 27 Aug. 1998. Accepted for publication 10 Dec. 1998. Research conducted at the University of Wisconsin-Madison. We appreciate the aid of Erik V. Nordheim with statistical analyses and the constructive comments of Larry $\mathrm{K}$. Binning and John C. Stier. This paper is based on a portion of a thesis to be submitted by J.M. Quintana in partial fulfillment for the requirements for the $\mathrm{PhD}$ degree in horticulture. The research was supported by the Graduate Research Committee at the Univ. of Wisconsin-Madison, the College of Agricultural and Life Sciences, and Hatch Act Funds. Use of trade names does not imply endorsement of the products named or criticism of similar ones not named. The cost of publishing this paper was defrayed in part by the payment of page charges. Under postal regulations, this paper therefore must be hereby marked advertisement solely to indicate this fact.

${ }^{1}$ Graduate Research Assistant.

${ }^{2}$ Professor.

${ }^{3}$ Associate Professor.

${ }^{4}$ Research Plant Breeder. pod Ca concentration could positively impact human nutrition.

A 1993 evaluation of pod Ca concentration of $60 \mathrm{~S}_{1}$ families and four cultivars of snap bean across two locations revealed significant differences among the genotypes (Quintana et al., 1996). The present study was designed to: 1) determine if application of $\mathrm{Ca}$ fertilizer to the soil would enhance Ca concentration in snap bean pods, and 2) compare the effects of two soil-applied $\mathrm{Ca}$ fertilizers on yield and pod $\mathrm{Ca}$ concentration.

\section{Materials and Methods}

Experimental design and treatments. A randomized complete-block design, with a factorial set of treatments including four cultivars and three $\mathrm{Ca}$ fertilizers with six replications, was used in 1996 and 1997 (three replications for yield). The four cultivars selected for differing ability to accumulate $\mathrm{Ca}$ in pods were Labrador (low accumulator), Hystyle and Evergreen (intermediate accumulators), and Top Crop (high accumulator). The $\mathrm{Ca}$ fertilizer treatments were: 1) $\mathrm{Ca}\left(\mathrm{NO}_{3}\right)_{2}$ containing $19.0 \% \mathrm{Ca}$ and $15.5 \% \mathrm{~N} ; 2) \mathrm{CaSO}_{4} \cdot 2 \mathrm{H}_{2} \mathrm{O}$ containing $22.3 \% \mathrm{Ca}$ and $18.6 \% \mathrm{~S}$; and 3 ) a control (no Ca applied).

Plant culture. The beans were planted on 20 June 1996 and 1997 at the Univ. of Wisconsin Hancock Experimental Station with each plot consisting of three rows $1.02 \mathrm{~m}$ long. In each row, 20 seeds were double-seeded and plants were thinned 2 weeks after planting to 10 seedlings per row $10.2 \mathrm{~cm}$ apart. Rows and blocks were spaced $91 \mathrm{~cm}$ apart with plot size $\approx 2.79 \mathrm{~m}^{2}$. The soil was characterized as Plainfield loamy sand with $1 \%$ organic matter.
Soil analysis taken prior to planting in 1996 showed a pH of 6.4 and concentrations $\left(\mathrm{mg} \cdot \mathrm{kg}^{-1}\right.$ ) of $72 \mathrm{P}, 75 \mathrm{~K}$, and $500 \mathrm{Ca}$. In 1997, soil $\mathrm{pH}$ was 5.5 and $\mathrm{P}, \mathrm{K}$, and Ca concentrations were 129,150 , and $600 \mathrm{mg} \cdot \mathrm{kg}^{-1}$, respectively.

Calcium was applied (total of $80 \mathrm{~kg} \cdot \mathrm{ha}^{-1}$ ) as: 1) $\mathrm{Ca}\left(\mathrm{NO}_{3}\right)_{2}$ applied in four applications each of $105 \mathrm{~kg} \cdot \mathrm{ha}^{-1}\left(20 \mathrm{~kg} \cdot \mathrm{ha}^{-1} \mathrm{Ca}\right)$ at 1 week prior to flowering, at flowering, and at 1 and 2 weeks after flowering; and 2) in a single application of $364 \mathrm{~kg} \cdot \mathrm{ha}^{-1} \mathrm{Ca}$ sulfate at planting time. All fertilizers were dissolved in $500 \mathrm{~mL}$ of water and hand-applied in bands 5 to $10 \mathrm{~cm}$ from the plants on both sides of the middle row and the inner sides of the outside rows. Fertilizer applications were scheduled $1 \mathrm{~d}$ after irrigation to minimize potential leaching. All fertilizer treatments were brought to the same rate of $\mathrm{N}\left(16.3 \mathrm{~kg} \cdot \mathrm{ha}^{-1}\right)$ with applications of ammonium nitrate $(33.5 \mathrm{~N}-0 \mathrm{P}-0 \mathrm{~K})$ in the $\mathrm{Ca}$ sulfate and control plots every time Ca nitrate was applied. Standard cultural practices included preplant incorporation of the herbicide trifluralin, cultivation as needed, an additional application of $33.5 \mathrm{~kg} \cdot \mathrm{ha}^{-1} \mathrm{~N}$ (15 d after planting), and an irrigation schedule of $12.5 \mathrm{~mm}$ per week from planting time until harvest (15 Aug. 1996 and 1997).

Sampling procedures. At harvest, most pods were full and seeds were small, which corresponded to plant life stages $-\mathrm{R}_{5}$ to $\mathrm{R}_{6}$ (Le Baron, 1974). The middle row was used for data collection (yield and samples for determination of pod Ca concentration). Only commercial sieve size number 4 pods ( 8.3 to 9.5 $\mathrm{mm}$ in diameter) were sampled for Ca determinations. Each pooled sample consisted of 10 to 15 pods per plot.

Laboratory and statistical analysis. Calcium extractions and determinations were as described in previous studies (Quintana et al., 1996). A pooled analysis of variance was performed on the data using SAS system software (SAS Institute, Cary, N.C.). Significant treatment means were separated using LSD tests.

Table 1. Mean effects of year, Ca fertilizer treatments, and cultivar on snap bean pod yield and pod $\mathrm{Ca}$ concentration.

\begin{tabular}{lcc}
\hline Source & $\begin{array}{c}\text { Yield } \\
\left(\mathrm{t} \cdot \mathrm{ha}^{-1}\right)\end{array}$ & $\begin{array}{c}\text { Ca } \\
\left(\mathrm{mg} \cdot \mathrm{g}^{-1} \text { dry wt }\right)\end{array}$ \\
\hline Year $^{\mathrm{z}}$ & $10.07 \mathrm{a}^{\mathrm{y}}$ & $4.68 \mathrm{~b}$ \\
1996 & $8.50 \mathrm{~b}$ & $5.41 \mathrm{a}$ \\
1997 & & \\
Fertilizer & $9.65^{\mathrm{Ns}}$ & $5.12^{\mathrm{Ns}}$ \\
Ca sulfate & 9.56 & 5.09 \\
Ca nitrate & 9.42 & 4.92 \\
Control & & \\
Cultivar & $11.27 \mathrm{a}$ & $5.28 \mathrm{a}$ \\
Hystyle & $9.77 \mathrm{~b}$ & $5.32 \mathrm{a}$ \\
Top Crop & $9.36 \mathrm{~b}$ & $5.47 \mathrm{a}$ \\
Evergreen & $7.77 \mathrm{c}$ & $4.09 \mathrm{~b}$ \\
Labrador &
\end{tabular}

${ }^{\mathrm{z}}$ Means for nine replicates (six in 1996 and three in 1997).

${ }^{\mathrm{y}}$ Mean separation within columns and sources by LSD, $P<0.05$.

${ }^{\mathrm{N}}$ Nonsignificant. 


\section{Results and Discussion}

Calcium fertilizer effects on pod Ca concentration and yield. Neither Ca nitrate nor $\mathrm{Ca}$ sulfate had a significant effect on pod $\mathrm{Ca}$ concentration or yield (Table 1). These results were consistent with a previous study in which three rates of Ca sulfate were evaluated on 12 snap bean cultivars (Miglioranza et al., 1997). Pod Ca concentration ranged from 4.92 to 5.12 $\mathrm{mg} \cdot \mathrm{g}^{-1}$ dry weight. Although yield increases have been recorded in response to soil applications of Ca fertilizer on potatoes (Simmons et al., 1988) at Hancock, Wis., the soil apparently contained enough $\mathrm{Ca}$ to fulfill snap bean requirements for normal development.

Cultivar effects on pod Ca concentration and yield. Differences in both pod Ca concentration and yield were found among cultivars (Table 1). The concentration was highest in 'Evergreen' ( $5.47 \mathrm{mg} \cdot \mathrm{g}^{-1}$ dry weight) and lowest in 'Labrador' (4.10 $\mathrm{mg} \cdot \mathrm{g}^{-1}$ dry weight) (Table 1). These results were consistent with observed genetic variation for efficiency of $\mathrm{Ca}$ use in snap beans (Quintana et al., 1996). Mean yield was highest in 'Hystyle' (18\% above the mean) and lowest in 'Labrador' (19\% below the mean). Cultivar $\times$ fertilizer interaction was nonsignificant for either variable $(P>0.05)$.

Environmental attributes. Strong year effects for pod Ca concentration and yield were observed (Table 1 ), but genotype $\times$ year inter- action was nonsignificant for any variable $(P$ $>0.05$ ). Mass flow is the primary mechanism for supplying $\mathrm{Ca}$ to the root surface (Barber, 1995). Thus, higher pod Ca concentration levels in 1997 may be due to the greater precipitation (260 $\mathrm{mm}$ in 1997 vs. $126 \mathrm{~mm}$ in 1996) and subsequent water availability for Ca transport, resulting in increased root $\mathrm{Ca}$ influx. Similarly, higher precipitation levels in 1997 may have resulted in increased $\mathrm{N}$ loss through leaching.

Interactions often exist between $\mathrm{Ca}$ and $\mathrm{pH}$, although not in soils with $\mathrm{pH}$ levels $\geq 5$ because these $\mathrm{Ca}$ solution concentrations are high when compared to the $\mathrm{H}$ concentrations (Barber, 1995). Thus, $\mathrm{pH}$ differences between years probably did not affect pod Ca concentration. The ability of snap bean plants to accumulate $\mathrm{Ca}$ in pods has been associated with the plant's capacity to transport xylem sap via root pressure (Quintana et al., 1997). Root pressure is usually greater when humidity is high (Kramer, 1983); and relative humidity was higher in 1997 , which possibly contributed to greater pod $\mathrm{Ca}$ concentrations.

Adding $\mathrm{Ca}$ to snap bean plants via soil fertilization did not increase pod Ca concentration or yield significantly. Cultivar effects had a greater impact than fertilizer treatments for all parameters measured, suggesting that breeding may more effective in enhancing pod $\mathrm{Ca}$ accumulation in beans.

\section{Literature Cited}

Barber, S.A. 1995. Soil nutrient bioavailability, a mechanistic approach. Wiley, New York.

Grusak, M.A., S. Pezeshgi, K.O. O'Brien, and S.A. Abrams. 1996. Intrinsic ${ }^{42} \mathrm{Ca}-$ labelling of green bean pods for use in human bioavailability studies. J. Sci. Food Agr. 70:11-15.

Kramer,P.J. 1983. Water relations of plants. Academic, New York.

Le Baron, M.J. 1974. Developmental stages of the common bean plant. Current Info. Ser. 228, Univ. of Idaho.

Macrae, R., R.K. Robinson, and M.J. Sadler. 1993. Encyclopedia of food science, food technology and nutrition. vol. 1. Academic, San Diego.

Miglioranza, E., P. Barak, K. Kmiecik, and J. Nienhuis. 1997. Comparison of soil and genotypic effects on calcium concentration of snap bean pods. HortScience 33:68-70.

Pao, E., K.H. Fleming, P.M. Guenther, and S.J. Mickle. 1982. Foods commonly eaten by individuals. U.S. Dept. of Agr./HNIS. Home Econ. Rpt. 44:408-409.

Quintana, J.M., H.C. Harrison, J. Nienhuis, J.P. Palta, and M.A. Grusak. 1996. Variation in calcium concentration among sixty $S_{1}$ families and four cultivars of snap bean (Phaseolus vulgaris L.). J. Amer. Soc. Hort. Sci. 121:789-793.

Quintana, J.M., H.C. Harrison, J.P. Palta, and J. Nienhuis. 1997. Flow rate as an important physiological factor associated to calcium concentration in pods of snap bean (Phaseolus vulgaris L.) plants grown aeroponically. HortScience 32:212. (Abstr.)

Simmons, K.E., K.A. Kelling, R.P. Wolkowski, and A. Kelman. 1988. Effect of calcium source and application method on potato yield and cation composition. Agron. J. 80:13-21. 